\author{
А.В. Смирнов \\ НИИ ревматологии РАМН, Москва
}

Рентгенологическое исследование костно-суставной системы кистей и стоп является обязательным при диагностике большинства ревматических заболеваний (Р3) [1]. Хронический полиартрит мелких суставов кистей и дистальных отделов стоп - характерное проявление многих Р3. Деструктивные поражения суставов (эрозии, остеолиз) при РЗ относятся к тяжелым патологическим состояниям скелета, имеющим прогрессирующее течение, что значительно снижает качество жизни больных, приводит к выраженным функциональным нарушениям суставов и инвалидизации больных. Особое социальное значение данным изменениям придает то, что они чаще всего обнаруживаются у лиц молодого и среднего, т.е. наиболее трудоспособного, возраста.

\section{Ревматоидный артрит}

Характерной особенностью ревматоидного артрита (РА) являются множественные и симметричные поражения суставов кистей и дистальных отделов стоп [2]. Первоначальные рентгенологические изменения чаще определяются во II-III пястно-фаланговых, III проксимальных межфаланговых суставах кистей. Одновременно или несколько позже появляются изменения в запястье, которое относится к комплексным синовиальным суставам, состоящим из нескольких простых (лучезапястного, переднего лучелоктевого, межзапястного, общего запястно-пястного, I запястно-пястного и гороховидно-трехгранного суставов), а также в V плюснефаланговых суставах. При РА поражаются все суставы запястья, что помогает в дифференциальной диагностике с другими хроническими артритами [3].

Изменения в стопах при РА выявляются в I-V плюснефаланговых и в I межфаланговых суставах; реже, в более поздние сроки заболевания, - в проксимальных межфаланговых суставах. Плюснефаланговые суставы вместе с суставами кистей очень часто (в 80-90\% случаев) вовлекаются в патологический процесс при РА [4].

К ранним рентгенологическим симптомам РА относятся околосуставной остеопороз (ОП), единичные или множественные кистовидные просветления костной ткани и сужение суставных щелей. Эти симптомы обнаруживаются при I и II стадии РА на доэрозивном этапе развития заболевания (рис. 1). Появление единичных эрозий относится ко II эрозивной стадии РА. Множественные эрозивные изменения суставов в сочетании с грубыми деформациями эпифизов костей наблюдаются при III стадии заболевания (рис. 2, 3). Появление костных анкилозов - отличительный признак РА, особенно если развива- ются множественные и симметричные анкилозы межзапястного и II-IV запястно-пястных суставов. Раньше всего анкилозируются суставы запястья (рис. 4), при этом все кости запястья могут сливаться в единый блок. В других суставах кистей костные анкилозы при РА не выявляются. Наличие единичных или множественных костных анкилозов относится к IV рентгенологической стадии РА.

\section{Псориатический артрит.}

При псориатическом артрите (ПсА) патологические изменения могут быть обнаружены во всех суставах (проксимальных и дистальных межфаланговых, пястно-фаланговых и плюснефаланговых, суставах запястья) кистей и стоп. Артриты сопровождаются околосуставным утолщением мягких тканей. В некоторых случаях они могут манифестировать диффузным утолщением мягких тканей пальцев кистей с характерной «сосискообразной» деформацией пальцев. Отсутствие околосуставного ОП является важным симптомом, отличающим ПсА от артритов при других Р3. В то же время наличие этого симптома в пораженных суставах не противоречит диагнозу ПсА. При ПсА могут встречаться как сужение, так и расширение суставной щели, при этом последнее выявляется более часто в мелких суставах кистей и связано с внутрисуставным остеолизом.

Эрозии в начале появляются в краевых отделах эпифизов костей, переходя на центральные отделы суставной поверхности. Часто результатом эрозирования или нейротрофических нарушений в концевых фалангах пальцев является акроостеолиз ногтевых бугристостей дистальных фаланг пальцев и/или внутрисуставной остеолиз эпифизов костей в проксимальных и дистальных межфаланговых суставах кистей. В случаях, когда преобладают выраженные деструктивные изменения в суставах в сочетании с описанными выше деформациями костей, используется термин «мутилирующий артрит» (рис. 5). Костные пролиферации - отличительная черта ПсА и других серонегативных спондилоартритов. Пролиферации обнаруживаются вокруг эрозий костей, часто выявляются также диафизарные и метафизарные периоститы. Костные пролиферации дистальных фаланг могут значительно повышать плотность костной ткани («фаланга слоновой кости»). Внутрисуставные костные анкилозы, особенно в проксимальных и дистальных межфаланговых суставах кистей, являются частыми находками и относятся к характерным симптомам ПсА (рис. 6).

Воспалительные энтезопатии характерны для ПсА, который проявляется в виде костных пролифераций раз- 
РЕ НТГЕ НОЛОГИ Ч С С АЯ ДИ АГ Н О С Т И А

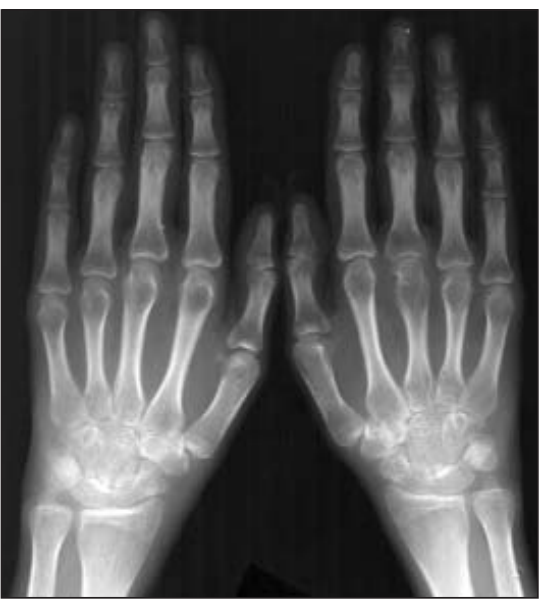

Рис. 1. Рентгенограмма кистей. РА II стадии. Выраженный околосуставной ОП. Сужение суставных щелей

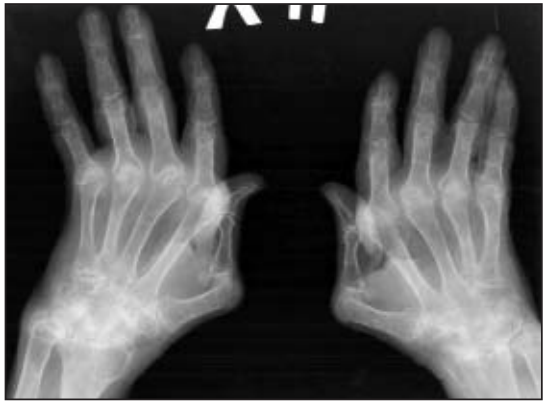

Рис. 4. Рентгенограмма кистей. РА

IVстадии. Выраженный распространенный ОП. Сужение суставных щелей. Множественные кисты и эрозии костей и суставных поверхностей. Вывихи и подвывихи суставов. Множественные анкилозы суставов запястья. Деформации костей. Вальгусная девиация пальцев («ластообразная кисть»)

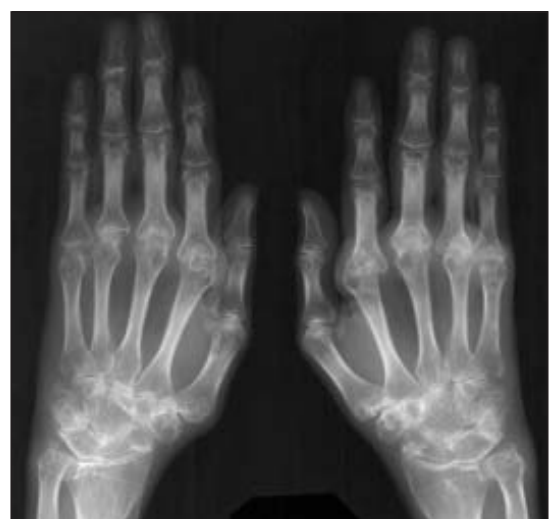

Рис. 2. Рентгенограмма кистей. РА III стадии. Выраженный околосуставной

ОП. Сужение суставных щелей.

Множественные кисты и эрозии костей и суставных поверхностей. Вывихи

и подвывихи пястно-фаланговых суставов. Деформации костей

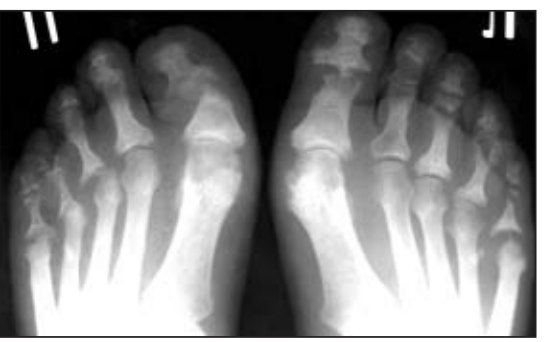

Рис. 5. Рентгенограмма дистальных отделов стоп. ПсА. Множественный внутрисуставной остеолиз. Симптом «карандаш в колпачке» І межфраланговых суставов стоп и Vлевого проксимального межффалангового сустава.

Подвывихи суставов. Множественные эрозии суставных поверхностей. Мутилирующий артрит

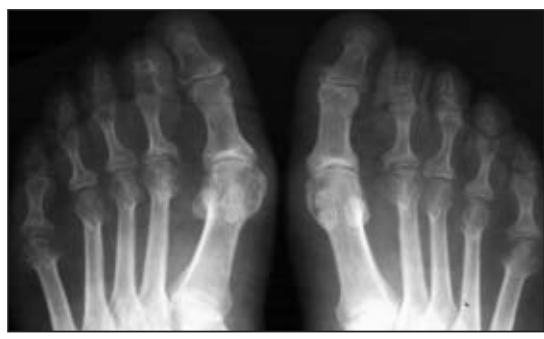

Рис. 3. Рентгенограмма дистальных отделов стоп. РА ІІІ стадии. Выраженный околосуставной ОП. Сужение суставных щелей. Множественные кисты и эрозии костей и суставных поверхностей. Множественные деформации плюсневых головок

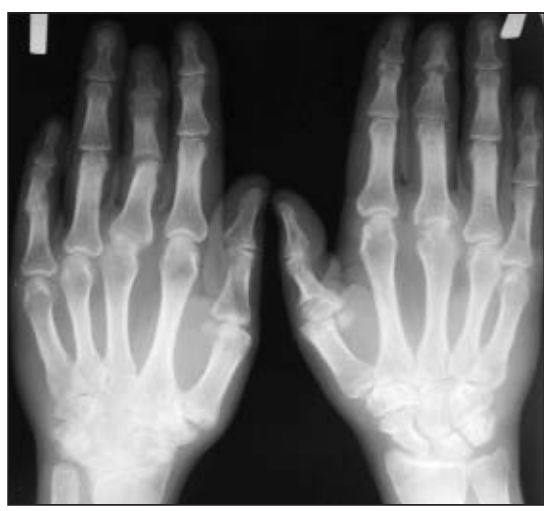

Рис. 6. Рентгенограмма кистей. ПсА. Асимметричный эрозивный полиартрит. Костный анкилоз III правого проксимального межфралангового сустава. Осевое поражение суставов III правого пальца. Остеолиз дистального эпифиза локтевой кости справа ной степени выраженности в местах прикрепления связок к костям. В кистях изменения часто выявляются в проксимальных и дистальных межфаланговых суставах и могут быть как одно-, так и двусторонними, симметричными или несимметричными. Эрозии обнаруживаются на краях суставных поверхностей костей и прогрессируют к центру, с формированием неправильных деструктивных изменений. Истончение (остеолиз) дистального отдела коротких трубчатых костей и протрузии их в основание сочленяющейся суставной поверхности формируют деформацию по типу «карандаша в колпачке» (см. рис. 5). Для ПсА характерно симметричное или асимметричное продольное эрозивное поражение суставов кистей одного уровня или осевое поражение трех суставов одного пальца. Отличительным признаком ПсА являются разнонаправленные деформации суставов.

\section{Болезнь Рейтера}

Типичным для болезни Рейтера (БР) является несимметричная распространенность изменений с преобладающим вовлечением в патологический процесс костей и суста- вов нижних конечностей [5]. По данным [6, 7], одной из наиболее характерных локализаций изменений при БР являются мелкие суставы дистальных отделов стоп. Значительно реже изменения обнаруживаются в мелких суставах кистей, где они чаще бывают неэрозивными.

Асимметричные артриты плюснефаланговых и проксимальных межфаланговых суставов стоп - наиболее частые проявления БР (рис. 7). Эти изменения встречаются у 40-65\% больных [8-10]. Наиболее часто обнаруживается артрит плюснефаланговых суставов, редко поражаются проксимальные межфаланговые суставы, рентгенологических признаков артрита в дистальных межфаланговых суставах не выявляется. Последнее отличает БР от ПсА, при котором поражение этих суставов встречается почти у трети больных. Изолированные и выраженные изменения межфалангового сустава I пальца стопы (рис. 8) предполагают в первую очередь диагноз БР или ПсА. При любой локализации патологического процесса в стопах околосуставной ОП, сужение суставных щелей, краевые эрозии с околосуставными костны- 
РЕ Н ТГЕ НО ЛОГИ Ч ЕС А Я ДИ АГ НО С Т И А

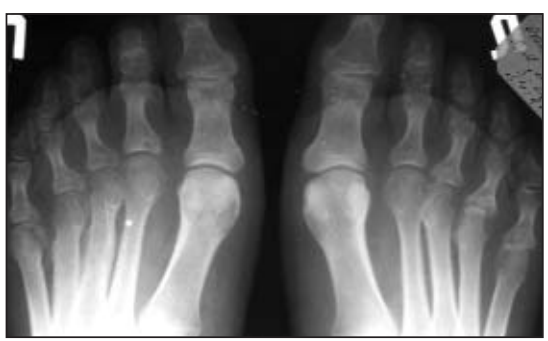

Рис. 7. Рентгенограмма дистальных отделов стоп. БР. Несимметричный эрозивный полиартрит с преобладанием изменений в III-Vплюснефаланговых суставах. Гиперостоз диафизов III и IV правых плюсневых костей

(деформации по типу «слоновой кости»)

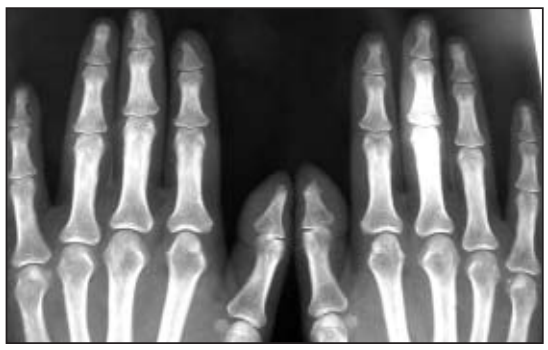

Рис. 10. Фрагмент рентгенограммы кистей. ССД. Акроостеолиз ногтевых бугристостей I и II дистальных фаланг пальцев

ми разрастаниями могут сочетаться с периоститами диафизов плюсневых костей и основных фаланг пальцев стоп. В плюснефаланговых суставах возможны подвывихи и деформации, при этом степень суставных поражений может иметь сходство с мутилирующим артритом, встречающимся при ПсА [11].

\section{Анкилозирующий спондилоартрит (болезнь Бехтерева)}

При анкилозирующем спондилоартрите (АС) встречаются изменения периферических суставов. В целом эти изменения сходны с таковыми при других заболеваниях из группы серонегативных спондилоартритов (БР и ПсА), но менее выражены. Симптомы поражения суставов включают в себя утолщение мягких тканей, умеренный ОП, сужение суставных щелей, костные эрозии и пролиферативные изменения костей [12]. Эрозии костей не такие глубокие, как при РА.

Наличие энтезопатий в местах прикрепления связок к костям и периоститов при АC, а также при других серонегативных спондилоартритах оказывают дополнительную помощь при постановке правильного диагноза.

\section{Системная склеродермия}

При системной склеродермии (ССД) часто наблюдаются рентгенологические изменения в мягких тканях, ко-

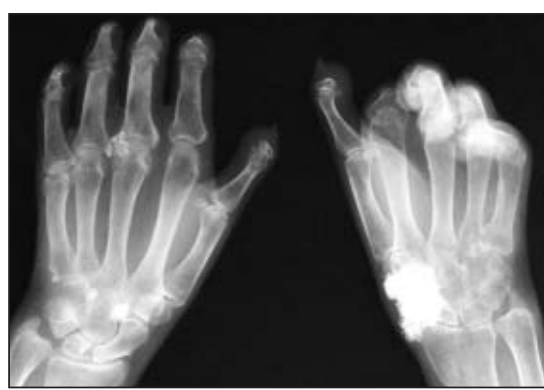

Рис. 9. Рентгенограмма кистей. ССД. Множественный остеолиз дистальных и средних фаланг пальцев. Множественные кальцификаты в мягких тканях (симптом Тибьержа-Вейссенбаха). Сгибательные контрактуры суставов. Выраженный распространенный ОП

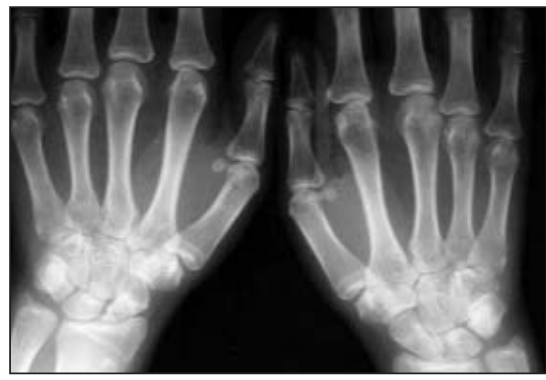

Рис. 12. Фрагмент рентгенограммы кистей. СКВ. Асептический некроз правой ладьевидной кости

стях и суставах кистей. Изменения в дистальных отделах стоп наблюдаются в единичных случаях и носят неспецифический характер. Патологические изменения мягких тканей кистей характеризуются их истончением, особенно концевых фаланг, и отложением кальцификата в подкожной жировой клетчатке и периартикулярных и артикулярных мягких тканях. Истончение мягких тканей связано с синдромом Рейно (СР) и встречается наиболее часто. Оно характеризуется уменьшением расстояния между кончиком фаланги и поверхностью кожи (в норме $>20 \%$ поперечного диаметра основания одноименной дистальной фаланги пальца) [13]. Со временем кончик пальца конически истончается, что часто сочетается с кальцификатами в мягких тканях этой области.

Кальцификаты в мягких тканях при ССД (симптом Тибьержа - Вейссенбаха) в основном встречаются в кистях, но могут обнаруживаться и в других суставах $[14,15]$ (рис. 9). Кальцификаты могут встречаться в подкожной жировой клетчатке, суставной капсуле, сухожилиях и связках. Они состоят главным образом из кристаллов гидроксиапатита и рентгенологически выявляются в виде небольших единичных или множественных округлых или линейной формы включений слабой или умеренной плот- 
РЕ НТГЕ НОЛОГИЧЕСКАЯ ДИАГИОСТ ИК А

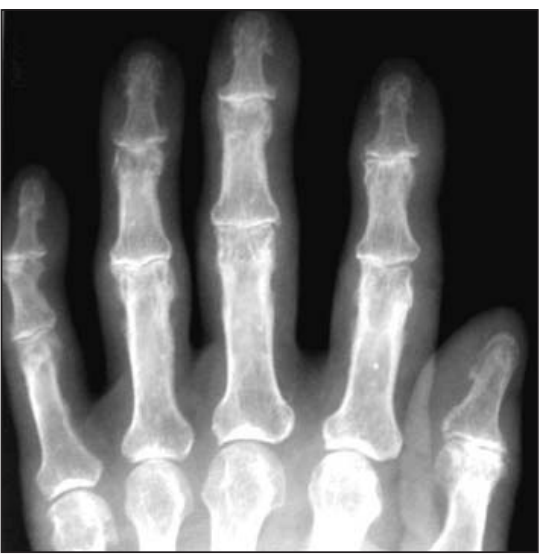

Рис. 13. Фрагмент рентгенограммы кисти. Первичный ОА II-III стадии дистальных и проксимальных межфаланговых суставов. Множественные узелки Гебердена и Бушара

ности. Также могут определяться крупные и множественные высокой плотности кальцифицированные конгломераты, располагающиеся в периартикулярных мягких тканях, описаны также внутрисуставные и внутрикостные кальцификаты.

Остеолиз фаланг пальцев рук частый рентгенологический симптом ССД. Наиболее частой и ранней локализацией остеолиза являются ногтевые бугристости дистальных фаланг пальцев (акроостеолиз), обычно они сочетаются с синдромом Рейно и кальцификацией мягких тканей. Вначале остеолиз захватывает только часть ногтевых бугристостей (рис. 10), но со временем распространяется на всю дистальную, а затем проксимальную фаланги и частично на дистальный эпифиз основной фаланги пальца (см. рис. 10). Необходимо отметить, что рассасывание фаланг пальцев при ССД имеет строгую направленность, описанную выше. Этим остеолиз отличается от внутрисуставного остеолиза в проксимальных и дистальных межфаланговых суставах кистей при ПсА, который может быть выявлен в любом из этих суставов при неизмененной ногтевой бугристости.

Иногда при ССД определяются признаки полиартрита в виде сужения суставных щелей, краевые и центральные костные эрозии и деформации костей. Отмечена тенденция к более частому, чем при других хронических артритах, поражению I запястно-пястных суставов [16]. Двусторонние деструктивные изменения в I запястно-пястных суставах с подвывихами и кальцинатами в мягких тканях должны вызывать подозрение на ССД.

\section{Системная красная волчанка}

Рентгенологические изменения в кистях при системной красной волчанке (СКВ) включают в себя симметричный полиартрит, чаще неэрозивный или с единичными поверхностными эрозиями, деформирующую неэрозивную артропатию, остеонекрозы, кальцификаты мягких тканей и ос-

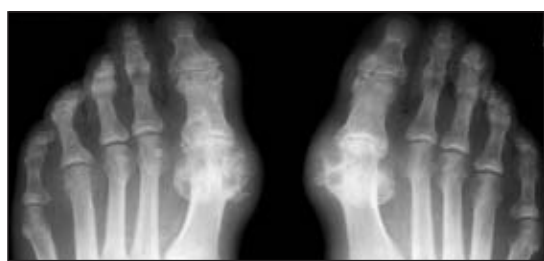

Рис. 15. Рентгенограмма дистальных отделов стоп. ПА. Утолщены и уплотнены мягкие ткани в I плюснефаланговых суставах. Множественные кисты со склеротическим ободком (симптом «пробойника»). Выражсенные пролиферативные костные изменения и множественные деструкции костей в I плюснефаланговых суставах. Кальцифицированы сосуды в мягких тканях

теосклероз дистальных фаланг пальцев (акросклероз) [17].

Хронический полиартрит при СКВ не имеет специфических черт и характеризуется утолщением мягких тканей, околосуставным ОП. Незначительное сужение суставных щелей, субхондральные кистовидные просветления костной ткани и единичные эрозии суставных поверхностей встречаются редко в эпифизе лучевой кости и пястных головках [18].

Деформирующая неэрозивная артропатия (синдром Жаку) отмечается у 5-40\% больных СКВ [17, 19]. Эти изменения обычно обнаруживаются в кистях. Выявляются костносуставные деформации по типу «лебединой шеи», «бутоньерки», а также в виде ульнарных девиаций в пястно-фаланговых суставах и подвывихов I запястно-пястного сустава с переразгибанием большого пальца кисти, что является особени
ной артропатии (рис. 11)

При СКВ могут быть обнаружены линейные и округлые кальцификаты в подкожной жировой клетчатке и периартикулярных мягких тканях в области запястий и пястно-фаланговых суставов [20] (см. рис. 11).

Внутрикостный остеосклероз дистальных фаланг (акросклероз) - частый рентгенологический симптом, который выявляется при СКВ. На рентгенограммах кистей обнаруживаются множественные склеротические уплотнения костной ткани, локализующиеся в центральных отделах дистальных фаланг пальцев [17].

Остеонекрозы - характерные изменения в суставах для определенной группы больных СКВ, что обусловлено длительным приемом глюкокортикоидов или системным васкулитом. Остеонекрозы при СКВ обнаруживаются в различных крупных суставах и костях запястья, особенно часто в ладьевидных костях запястья, и проявляются кистовидной перестройкой со склеротическими изменениями в центральной части кости, разрушением и вторичной ее деформацией (рис. 12). 


\section{РЕ Н ТГЕ НО ЛОГИ Ч ЕС А Я Д И АГ НО С Т И А}

Хронический полиартрит, волчаночная артропатия и остеонекрозы костей приводят в финальной стадии к вторичному остеоартрозу (ОА) суставов кистей.

\section{Первичный остеоартроз}

ОА - хроническое прогрессирующее заболевание суставов, характеризующееся дегенерацией суставного хряща, изменениями в субхондральном отделе эпифизов костей и околосуставных мягких тканях.

Рентгенография остается наиболее простым и общедоступным методом исследования суставов для оценки анатомических изменений структуры костей при ОА. Характерные рентгенологические проявления ОА обычно легко определяются на стандартных рентгенограммах суставов. Это сужение рентгеновской суставной щели, субхондральный остеосклероз и остеофиты на краях суставных поверхностей. Данные рентгенологические симптомы рассматриваются как специфические для ОА, используются для постановки диагноза ОА и входят в рентгенологические критерии в сочетании с клиническими критериями диагностики ОА, разработанными [21].

Первая известная классификация рентгенологических изменений по степени выраженности ОА, в которой были выделены 4 стадии основных рентгенологических признаков ОА, была предложена J.H. Kellgren и J.S. Lawrence в 1957 г. [22]:

- Начальные проявления (соответствуют I-II стадиям артроза по Kellgren): заострения или небольшие остеофиты на краях суставных поверхностей с нерезким субхондральным остеосклерозом; мелкие субхондрально расположенные кисты при нормальной или слегка суженной суставной щели. Мелкие кальцификаты в мягких тканях в области боковых краев суставных поверхностей костей (рис. 13).

- Выраженные изменения (соответствуют III-IV стадиям артроза по Kellgren): крупные остеофиты и деформация краев суставных поверхностей, значительное сужение суставных щелей, субхондральный остеосклероз, кисты со склеротическим ободком, краевые дефекты суставных поверхностей (псевдоэрозии суставных поверхностей костей), при этом костные выступы на суставной поверхности одной кости могут вклиниваться в сочленяющуюся суставную поверхность другой кости и формировать типичный для ОА мелких суставов кистей симптом «летящей чайки». Крупные остеофиты на краях суставных поверхностей, расположенные перпендикулярно оси дистальной фаланги, образуют другой характерный симптом «перевернутого Т». Обычно краевые дефекты костной ткани окружены зоной остеосклероза (рис. 14).

Остеофиты, кальцификаты и перифокальное уплотнение мягких тканей в краевых отделах суставных поверхностей формируют узелки Гебердена (см. рис. 14) в дистальных межфаланговых суставах и узелки Бушара (см. рис. 14) в проксимальных межфаланговых суставах.

Изменения в I запястно-пястных суставах кистей и в I плюснефаланговых суставах стоп являются типичными для первичного ОА. Начальными симптомами ОА в этих суставах являются небольшие заострения краев или остеофиты с нерезким субхондральным остеосклерозом; мелкие субхондрально расположенные кисты, чаще по медиальному краю плюсневой головки (в I плюснефаланговом суставе) и на наружных краях проксимального эпифиза I пястной кости и трапециевидной кости запястья (в I за- пястно-пястном суставе) при нормальной или слегка суженной суставной щели. Для более выраженных стадий ОА характерны крупные остеофиты и деформация краев суставных поверхностей, значительное сужение суставных щелей, субхондральный остеосклероз, кисты со склеротическим ободком. Обычно кистовидные просветления костной ткани окружены зоной остеосклероза. Типичным надо считать и сочетание ОА I плюснефаланговых суставов с вальгусной девиацией суставов и деформацией трапециевидной кости в I запястно-пястном суставе.

\section{Подагрический артрит}

Для подагрического артрита (ПА) характерно преимущественное поражение суставов дистальных отделов стоп с преобладанием изменений в I плюснефаланговых суставах. Значительно реже изменения выявляются в мелких суставах кистей. Ранним рентгенологическим симптомом ПА является преходящее утолщение мягких тканей в измененных суставах в течение острой подагрической атаки. С переходом заболевания в хроническую стадию выявляются типичные для ПА узловые образования (тофусы) в костях (в виде кистовидных просветлений костной ткани) и в мягких тканях (в виде участков повышения ее плотности) в области фаланг пальцев кистей и стоп. В отдельных наблюдениях можно обнаружить частичную кальцификацию внутри тофусов, что сочетается у больных с подагрическим нефритом, но данный симптом обнаруживается редко [12].

Костные эрозии часто выявляются при хроническом течении ПА. Внутрисуставные эрозии локализуются в основном на краях эпифизов костей и в дальнейшем распространяются на центральные отделы суставов. Внесуставные эрозии определяются в области метадиафизов костей и часто взаимосвязаны с мягкотканными тофусами. Эрозии при ПА имеют округлую или овальную форму, часто со склеротическим ободком. Склеротический ободок в основании эрозии или вокруг внутрикостного тофуса создает типичный для ПА рентгенологический симптом «пробойника». Краевая эрозия кости в виде «свешивающейся губы» - еще один характерный для ПА рентгенологический признак. Выраженная пролиферативная реакция, отражающая репаративные процессы в костях, может быть обнаружена в плюснефаланговых и межфаланговых суставах (рис. 15).

При ПА ширина рентгенологической суставной щели обычно сохраняется в норме даже в поздних стадиях заболевания. Наличие внутрисуставной кальцифицированной костной эрозии с сохраненной шириной суставной щели в первую очередь предполагает диагноз ПА.

Иногда может обнаруживаться внутрисуставной костный анкилоз межфаланговых суставов стоп. Преходящий локальный ОП наблюдается только во время острой подагрической атаки. Для хронической стадии ПА нехарактерен ОП.

Основные рентгенологические симптомы ПА сходны во всех местах поражения, однако изменение специфических для ПА областей может быть диагностически важным [12]. I плюснефаланговый сустав - наиболее характерная локализация поражения при ПА. Эрозии обычно обнаруживаются в верхней и медиальной части плюсневой головки и часто в сочетании с вальгусной девиацией суставов. Нередко определяются изменения в 


\section{РЕ Н ТГЕ Н О ЛОГИ Ч ЕС А Я Д И АГ НО С Т ИКА}

проксимальных и дистальных межфаланговых суставах стоп. Типичными являются асимметричные артриты с чередованием внутрикостных и мягкотканных тофусов. Крупные мягкотканные и внутрикостные тофусы могут вызывать остеолиз больших участков костей, в основном это метадиафизы костей, но в проксимальных и дистальных фалангах пальцев кистей и стоп возможен тотальный остеолиз костей [14] (рис. 16).

В заключение отметим, что для более точной и детальной оценки патологических изменений в костях, суставах и мягких тканях стопы, а также мелких суставах кистей необходим весь спектр новейших диагностических технологий
- прицельная рентгенография с прямым увеличением изображения; стандартная рентгенография костей и суставов с использованием специализированной рентгеновской пленки и соответствующих усиливающих экранов в кассетах или с запоминающими экранами высокого разрешения без использования рентгеновской пленки; магнитно-резонансная томография для ранней (дорентгенологической) диагностики поражения костей и суставов; спиральная компьютерная томография для более точного выявления внутрикостных изменений; УЗИ суставов для оценки периартикулярных мягких тканей как наиболее простой и лишенный лучевой нагрузки на пациента метод.

Л И

1. Ревматология: национальное руководство. Под ред. В.А. Насоновой и Е.Л. Насонова. М.: ГЭОТАР-Медиа, 2008: 720 с. 2. Смирнов А.В. Атлас рентгенологической диагностики ревматоидного артрита. М.: ИМА-пресс, 2009;56 с.

3. Астапенко М.Г. Характеристика суставного синдрома при ревматоидном артрите. Ревматоидный артрит. М., 1983;70-3. 4. Thould A., Simon G. Ann Rheum Dis 1966;25:220.

5. Murray R., Oates J., Young A. Radiologic changes in Reiter's syndrome and arthritis associated with urethritis. J Fac Radiologists 1958;9:37-43.

6. Сидельникова С.М., Агабабова Э.Р., Копьева Т.Н. Некоторые аспекты хронического течения болезни Рейтера. Тер арх 1986;7:29-34.

7. Насонова В.А., Астапенко М.Г., Агабабова Э.Р. Болезнь Рейтера. В кн.: Клиническая ревматология. М., 1989;348-56. 8. Смирнов А.В., Мылов Н.М.,

Шубин С.В. Клинико-рентгенологическая характеристика при болезни Рейтера. Клин ревматол 1994;4:22-4.

9. Sholkoff S., Glickman M., Steinbach H. Roengenology of Reiter's syndrome. Radiology 1970;97:497-509.

10. Weldon W., Scaletter R. Roentgen changes in Reiter's syndrome. Am J Roengenol 1961;86:344-58.

11. Steinbach H., Jensen P.

Roentgenographic Changes in the Arthritides (Part 2). Reiter's Syndrome. Seminars Arthr Rheum 1976;5:203-46.

12. Resnick D. In: Resnick D. and Niwayama G. Diagnosis of Bone and Joint Disorders. Philadelphia: W.B. Saunders Company, 1981. 13. Poznanski A.K. The Hand in Radiologic Diagnosis. Philadelphia: W.B. Saunders Company, 1974;531 c.

14. Смирнов А.В. Дифференциальная рентгенологическая диагностика поражения суставов кисти при ревматических заболеваниях. Consilium medicum 2005;7(2):75-82. 15 . Resnick D. Scleroderma (progressive systemic sclerosis). In: Resnick D and Niwayama G. Diagnosis of Bone and Joint Disorders. Philadelphia: W.B. Saunders Company,
$1981 ; 1204 \mathrm{c}$.

16. Lovell C.R., Jayson M.I. Joint involvement in systemic sclerosis. Scand J Rheumatol 1979;8:154

17. Weissman B.N., Rappoport A.S.,

Sosman J.L. et al. Radiographic findings in the hands in patients with systemic lupus erythematosus. Radiology 1978; 126:313.

18. Kelley W.N., Harris E.D., Ruddy S. et al. Textbook of Rheumatology. $4^{\text {th }}$ ed. V.1. 1993. 19. Bywaters E.G.L. Jaccoud's syndrome: a sequel to the joint involvement in systemic lupus erythematosus. Clin Rheum Dis 1975;1:125.

20. Budin J.A., Feldman F. Soft Tissue calcification in systemic lupus erythematosus. Am J Roentgenol 1975;124:358.

21. Беневоленская Л.И., Алексеева Л.И. Диагностические критерии остеоартроза. В сб.: Современные проблемы ревматологии. Тезисы докладов 1-го съезда ревматологов России. Оренбург, 1993;191-2.

22. Kellgren J.H., Lawrence J.S. Radiological assessment of osteoarthrosis. Ann Rheum Dis $1957 ; 16: 494-501$.

\section{У В А Ж АЕ М Ы Е К О Л Л ЕГ И !}

Подписаться на журнал “СОВРЕМЕННАЯ РЕВМАТОЛОГИЯ" можно через КаталогИ: «Пресса России». Подписной индекс - 42195.

«Почта России» (каталог «Персональная подписка», только для организаций с доставкой заказной бандеролью). Подписной индекс - К 0861.

Журнал выходит 4 раза в год (раз в квартал).

Чтобы получать журнал по рассылке, необходимо прислать заполненную анке ту (см. анкету на с. 92) по адресу: 123104, Москва, а/я 68, Издательство «ИМА-ПРЕСС» или по электронной почте: info@ima-press.net.

Поскольку есть случаи, когда почта возвращает журнал в редакцию из-за неточно указанного адреса, просим всех подписчиков разборчиво писать адрес.

Если вы подписались на журнал и не получили его, просим прислать заявку еще раз.

\section{Электронная версия журнала:}

на сайте НИИР РАМН http://rheumatology.beweb.ru/doctor/zhurnaly/sr/

в Научной электронной библиотеке http://www.elibrary.ru 